\title{
PELATIHAN PEMBUATAN HAND SANITIZER PERASAAN BUAH JERUK NIPIS BAGI GURU, SISWA SISWI SMA DAN SMK MUTIARA 17 AGUSTUS KELURAHAN TELUK PUCUNG BEKASI UTARA
}

Pramulani Mulya Lestari*, Ani Pahriyani

Fakultas Farmasi dan Sains Universitas Muhammadiyah Prof Dr. HAMKA

\begin{abstract}
Abstrak
Hand sanitizer (antiseptik tangan) adalah produk kesehatan yang secara instant dapat mematikan kuman tanpa menggunakan air, dapat digunakan kapan saja dan dimana saja, misalnya setelah memegang uang, sebelum makan, setelah dari toilet dan setelah membuang sampah. Tujuan dari kegiatan pengabdian ini dapat menghasilkan suatu produk kesehatan yang dapat dimanfaatkan baik untuk diri sendiri, keluarga dan masyarakat sekitarnya. Metode yang digunakan berupa ceramah berisi penjelasan materi dan praktek pembuatan hand sanitizer. Hasil dari pengabdian masyarakat ini adalah pemahaman peserta tentang pembuatan hand sanitizer dari bahan alam beserta fungsinya.
\end{abstract}

\section{PENDAHULUAN}

Kesehatan merupakan aspek yang sangat penting bagi kehidupan, suatu cara untuk menjaganya dengan memelihara kebersihan tangan. Saat ini banyak ditawarkan pembersih tangan berupa hand sanitizer karena penggunaannya lebih praktis. Hand sanitizer (antiseptik tangan) adalah produk kesehatan yang secara instant dapat mematikan kuman tanpa menggunakan air, dapat digunakan kapan saja dan dimana saja, misalnya setelah memegang uang, sebelum makan, setelah dari toilet dan setelah membuang sampah. Akan tetapi penggunaan alkohol pada kulit dirasa kurang aman karena alkohol adalah pelarut organic yang dapat melarutkan sebum pada kulit, dimana sebum tersebut bertugas melindungi kulit dari mikroorganisme (Retnosari dan Isadiartuti, 2006). Berdasarkan permasalahan tersebut maka muncul pertimbangan untuk menghilangkan kandungan alkohol pada sediaan hand sanitizer dengan mencoba menggunakan bahan alami.

Ada banyak tanaman yang dapat dimanfaatkan sebagai bahan alami pembuatan hand sanitizer, salah satunya yaitu jeruk nipis. Jeruk Nipis (Citrus aurantifolia S.) merupakan salah satu tanaman yang mudah didapatkan di lingkungan masyarakat dan banyak digunakan sebagai ramuan tradisional atau campuran sebagai perisa atau aroma. Selain digunakan sebagai aroma, jeruk nipis juga mengandung unsur-unsur senyawa kimia yang bemanfaat, seperti minyak atsiri yang mempunyai fungsi sebagai antibakteri yaitu flavanoid yang dapat menghambat pertumbuhan Staphylococcus aereus (kuman pada kulit) dan juga memiliki aroma yang khas (Dewi, 2012). Pada penelitian (Lauma, 2015) menyatakan bahwa perasan air jeruk nipis memiliki efek antibakteri dalam menghambat pertumbuhan bakteri Staphylococcus aureus, hal ini ditunjukan dengan terbentuknya zona hambat perasan air jeruk nipis terhadap Staphylococcus aureus sebesar $14,22 \mathrm{~mm}$.

Melihat manfaat yang cukup besar dari perasan air buah jeruk nipis ini dalam pembuatan Hand sanitizer maka dirasa perlu untuk disampaikan pengetahuan yang baik ini kepada siswa siswi sekolah dapat terlaksana melalui Program Pemberdayaan dan Pengabdian Masyarakat (PPPM) yang dilakukan Fakultas Farmasi dan Sains UHAMKA. Kegiatan PPPM ini mencakup 
cara pembuatan hand sanitizer. Dengan memberikan pengetahuan dan cara pembuatannya kepada siswa siswi diharapkan siswa siswi dapat meningkatkan derajat kesehatannya secara mandiri serta meningkatkan pendapatan ekonomi.

Sehubungan dengan hal tersebut, tim dosen FFS UHAMKA merencanakan kegiatan pengabdian dan pengembangan yang berkaitan dengan masalah pengembangan kreativitas bagi guru, siswa siswi sekolah SMA dan SMK Mutiara 17 Agustus, Kota Bekasi, Jawa Barat. Lokasi mitra berjarak $\pm 20 \mathrm{~km}$ dan dapat ditempuh sekitar 1,5 jam dari kampus FFS UHAMKA mengasilkan luaran yang baik. Adapun luaran yang diharapkan dari pengabdian ini yaitu dapat diproduksinya handsanitizer dari perasan jeruk nipis.

\section{METODE PELAKSANAAN}

Upaya untuk menyelesaikan permasalahan yang dihadapi mitra berupa pelatihan pembuatan hand sanitizer sebagai berikut:

\section{Materi tertulis}

Materi tertulis meliputi penjelasan rinci tentang cara definisi, fungsi serta ringkasan pembuatan hand sznitizer.

Metode Praktek

Tahap Penyiapan
a. Buah jeruk nipis
b. Carboxi Metyl Celullose
c. Propylenglycol
d. Aquadest
e. Etanol
f. Na. metabisulfit
g. Nipagin
h. Lumpang dan alu

\section{i. Hot Plate}

j. Kain Flanel

Tahap pelaksanaan

a. Pembuatan sari buah jeruk

b. Proses pembuatan sari buah nanas dilakukan dengan cara : memeras jeruk nipis dan disaring dengan kain flanel untuk memisahkan hasil perasan dengan ampasnya. Sari buah yang diperoleh lalu ditimbang.

c. Pembuatan sediaan masker gel peel-off sari buah nanas

d. Bahan- bahan ditimbang

e. CMC ditambahkan dengan propilenglikol lalu diaduk sampai dengan semua permukaan serbuk CMC basah lalu tambahkan aquadest sampai terbentuk gel (massa 1)

f. Nipagin dilarutkan dalam etanol (massa 2)

g. Na. Mitabisulfit dilarutkan dalam aquadest (massa 3)

h. Campur ke tiga masa tersebut lalu masukkan semua sisa aquadest hingga cairan hand sanitizer siap untuk digunakan. Tim pelaksana merupakan staf pengajar dengan bidang keahlian farmasi yang secara khusus memahami dan berkompeten dalam pembuatan dan pengembangan produk farmasi seperti obat, kosmetika, makanan dan minuman kesehatan. Dengan keahlian yang dimiliki oleh tim pelaksana diharapkan dapat membantu siswa siswi dalam meningkatkan derajat kesehatan dan ekonomi melalui pembuatan masker gel peel-off secara sederhana

Evaluasi

Setelah dilakukan simulasi pembuatan produk maka selanjutnya dilakukan evaluasi 
secara organoleptis dan sensitivitas maupun iritabilitas terhadap kulit

\section{HASIL DAN PEMBAHASAN}

Kegiatan pengabdian kepada guru, siswa - siswi SMA dan SMK Farmasi Mutiara 17 agustus ini bertujuan untuk meningkatan pemahaman/pengetahuan siswa siswi SMK Farmasi tentang banyaknya manfaat yang dikandung buah jeruk nipis sebagai salah satu kekayaan alam Indonesia. Dalam kegiatan inipula diharapkan dapat meningkatan keterampilan melalui pelatihan pembuatan handsanitizer dari sari buah jeruk nipis dengan metode sederhana dan biaya yang relatif terjangkau.

Hands sanitizer adalah produk kesehatan yang secara instant dapat menghambat dan mematikan kuman tanpa menggunakan air, dapat digunakan kapan saja dan dimana saja. Sediaan ini populer digunakan karena penggunaannya yang mudah dan praktis tidak membutuhkan air dan sabun. Masayarakat menggunakan produk ini biasanya saat tangan akan digunakan sebelum makan, setelah dari toilet dan setelah membuang sampah. Terdapat berbagai jenis bakteri yang mudah menempel di tangan manusia seperti staphylococcus aureus, E.colli, salmonella dan shigella. Bahan makanan yang disiapkan dengan kontak tangan langsung tanpa proses mencuci tangan sangat berpotensi terkontaminasi bakteri-bakteri tersebut.

Kegiatan ini diselenggarakan pada tanggal 6 Januari 2018 dan dihadiri oleh para guru, siswa siswi SMA dan SMK Farmasi Mutiara 17 Agustus, Bekasi. Respon peserta terhadap pelatihan ini terlihat sangat antusias mengingat sanitizer sering digunakan dalam keseharian peserta baik di rumah ataupun menjadi teman saat dalam perjalanan. Selain itu buah jeruk nipis sendiri mudah ditemukan dan memiliki banyak manfaat. Walaupun pengetahuan dssara tentang produk-produk farmasi telah diketahui oleh sebagian besar peserta, namun aplikasi dari pengetahuan dasar tersebut sama sekali belum dilaksakan atau dengan kata lain masih sangat terbatas. Pelatihan ini dapat memberikan solusi pembuatan sediaan untuk kesehatan pribadi dengan harga yang sangat terjangkau dan bahan yang mudah didapat, serta memiliki nilai ekonomis yang tinggi, karena setelah diolah bahan - bahan ini dapat menghasilkan suatu produk yang memiliki nilai jual yang cukup tinggi.

Pelatihan ini diawali dengan penyuluhan tentang manfaat dan kandungan hand sanitizer berbahan dasar jeruk nipis. Hal ini bertujuan agar peserta dapat mengetahui betapa banyak manfaat menggunakan hand sanitizer buah jeruk nipis yang bahan - bahannya bisa didapat disekitar kita, bahkan dapat ditemui dalam kehidupan sehari - hari. Diskusi seputar manfaat masker gel ini berlangsung cukup panjang, karena rasa ingin tahu siswa - siswi yang cukup tinggi, termasuk pemanfaatan buah lain yang mungkin juga dapat digunakan sebagai bahan dasar hand sanitizer. Tahapan selanjutnya adalah pembuatan produk hand sanitizer.

Sanitizer yang ideal harus memiliki beberapa hal seperti memiliki sifat menghancurkan mikroba, aktif melawan fase vegetatif bakteri, kapang dan khamir. Selain itu, sanitizer juga harus mampu bertahan atau aktif walaupun dalam lingkungan yang mengandung bahan organik seperti deterjen, sisa sabun, kesadahan air dan perbedaan $\mathrm{pH}$. Untuk memenuhi standar tersebut maka telah 
dilakukan beberapa penelitian sebelumnya sebelum kegiatan ini dilaksanakan. Hasilnya adalah berupa hand sanitizer yang mampu membersihkan dengan baik ditandai dengan uji terhadap mikroba, stabil, mudah digunakan dan tidak beracun.

Komposisi hand sanitizer berupa perasan jeruk nipis, lidah buaya, etyl alkohol, HPMC dan aquades. Jeruk nipis mengandung unsur-unsur senyawa kimia yang bermanfaat misalnya limonene, linalin asetat, fellandren dan sitral. Sari jeruk nipis dimanfaatkan di dalam industri kosmetik sebagai bahan untuk memperkecil pori-pori wajah, membersihkan dan menyegarkan. Beberapa penelitian yang telah dilakukan membuktikan air perasan jeruk nipis yaitu staphylococcus aureus, streptococcus mutans, salmonella thyposa. Komposisi lain yaitu berupa lidah buaya. Lidah buaya membantu menyembuhkan luka, lidah buaya mengandung senyawa glukomanan yakni senyawa yang memicu pertumbuhan sel kulit, membantu kulit membentuk kolagen, mengurangi peradangan dan melembabkan kulit.

UCAPAN TERIMA KASIH

Kepada LPPM UHAMKA, SMA dan

\section{DAFTAR PUSTAKA}

Anief, M., 2007, Farmasetika, UGM Press, Yogyakarta

Anonim, 1986, Sediaan Galenik. Departemen Kesehatan Republik Indonesia, Jakarta.

Anonim, 1997. Farmakope Indonesia Edisi IV. Departemen Kesehaan Republik Indonesia

Anonim. 1983. Farmakologi dan Terapi edisi II. Bag. Farmakologi FK UI. Jakarta.
Setelah rangkaian pembuatan produk selesai maka peserta dapat langsung merasakan produk yang telah dibuat sehingga pelatihan ini benar-benar dirasakan manfaatnya. Selain itu produk yang telah dibuat dikemas dalam bentuk sederhana dan dapat digunakan baik di rumah maupun diperjalan oleh peserta. Hal ini sesuai dengan luaran yang diharapkan yakni berupa produk yang dapat dibuat dengan cara sederhana dan dengan biaya yang cukup murah.

\section{KESIMPULAN}

Kegiatan pengabdian kemitraan masyarakat bagi guru-guru, siswa siswi SMA dan SMK Mutiara 17 Agustus mendapat respon yang cukup baik. Produk yang dibuat dapat langsung diaplikasikan karena terbuat dari bahan alam. Semua peserta tidak merasakan adanya alergi atau iritasi dan rasa terbakar setelah dilakukan pengamatan pasca penggunaan handsanitizer.

SMK Mitra 17 Agustus sebagai mitra

Block, S. 2001. Disinfection, Sterilization and Preservation, edisi 4, Williams and Wilkins. USA.

Dewi, Desintya. 2012. Khasiat dan Manfaat Jeruk Nipis. Surabaya : Penerbit Stomata.

Hidayat, S., 2005, Ramuan Tradisional ala 12 Etnis Indonesia, 6, Penebar Swadaya, Jakarta.

Lauma, S.W., Pangemanan, Damajanti H. C., Bernart S. P Hutagalung. 2015. Uji Efektifitas Perasan Air Jeruk Nipis 
Jurnal SEMAR, ISSN 2302-3937

Vol.6 No.3 September 2018

(Citrus aurantifolia S) Terhadap Pertumbuhan Bakteri Staphylococcus aureus Secara In Vitro. Jurnal Ilmiah Farmasi-Unsrat. Vol. 4 No.4.

Radji, M., 2011, Buku Ajar Mikrobiologi Panduan Mahasiswa Farmasi dan Kedokteran, 107, 118, 201-203, 297, Buku Kedokteran EGC, Jakarta.

Retnosari dan Isadiartuti, D.,2006. Studi Efektivitas Sediaan Gel Antiseptik Tangan Ekstrak Daun Sirih (Piper betle Linn.). Majalah farmasi Indonesia.

Sutjipto, 2001. Inventaris Tanaman Obat Indonesia, Jilid 2. Departemen Kesehatan dan Kesejahteraan Sosial Republik Indonesia. Badan Penelitian dan Pengembangan Kesehatan. Jakarta. Hal : 145-146.

Winarti, C. dan Nurdjanah, N., 2005, Peluang Tanaman Rempah dan Obat Sebagai Sumber Pangan Fungsional, Jurnal Litbang Pertanian, 24(2), 47-5 